\title{
Indian practice on estimation of scour around bridge piers-A comment
}

\author{
UMESH C KOTHYARI \\ Department of Civil Engineering, Indian Institute of Technology, Roorkee 247667 \\ e-mail: umeshfce@iitr.ernet.in
}

MS received 27 December 2005; revised 25 September 2006

\begin{abstract}
Well-laid foundation is mostly provided in road and railway bridges in India over large and medium-sized rivers. The age-old Lacey-Inglis method is used for estimation of the design scour depth around bridge elements such as pier, abutment, guide bank, spur and groyene. Codal provisions are seen to produce too large a scour depth around bridge elements resulting in bridge sub-structures that lead to increased construction costs. Limitations that exist in the codes of practice are illustrated in this paper using examples. The methods recently developed for estimation of the scour are described. New railway and road bridges are required to be built in large numbers in the near future across several rivers to strengthen such infrastructure in the country. It is strongly felt that provisions in the existing codes of practice for determination of design scour depth require immediate review. The present paper provides a critical note on the practices followed in India for estimating the design scour depth.
\end{abstract}

Keywords. Bridge elements; scour depth; design scour; Lacey-Inglis method.

\section{Introduction}

"Man who overlooks the water under bridge will find the bridge under water". This anonymous citation highlights the detrimental effects that river flow can have on the stability of piers and abutments that support a bridge founded in river. The main cause of concern in stability of bridges founded in river-beds is the lowering of river-bed level caused by river flow around bridge elements such as piers, abutments and spur dikes and is termed 'local scour'.

An accurate estimation of scour depth below stream-bed during design is important since this determines the foundation levels of the bridge elements such as pier, abutment, guide bank, spur, groyene, etc. Following the Scholarie Creek Bridge failure in the State of New York in 1987, which killed 10 people, the US Federal Highway Administration mandated that all state highway agencies evaluate existing and proposed bridges for susceptibility to scour-related failure. Huber (1991) stated that since 1950 about 500 bridges failed in USA and that a majority of them were the result of hydraulic conditions primarily due to the scour of foundation material. Such data on bridge failures in India due to scour is not available. Although scour has been a matter of concern to the railway and public work departments in 
the country, only a few hydrologic and scour studies have been undertaken by governmental agencies like the Ministries of Surface Transport and Railways (Gupta 2003). The depth of scour below the river-bed level around bridge elements in alluvial streams can be very large depending on flow, pier and sediment characteristics. The foundations of bridge piers should therefore have a great depth below the river-bed (up to $50 \mathrm{~m}$ ) in case of large rivers like the Ganga and the Brahmputra. Considerable cost would be saved in the construction of bridge foundations if the maximum scour depth is realistically estimated during design.

\section{Mechanism of scour}

The boundary layer in the flow past a bridge element undergoes a three-dimensional separation. This separated shear layer rolls up along the obstruction to form a vortex system in front of the element which is swept downstream by the river flow. Viewed from the top, this vortex system has the characteristic shape of a horseshoe and thus called a horseshoe vortex (figure 1). The formation of the horseshoe vortex and the associated downflow around the bridge element results in increased shear stress and hence a local increase in sediment transport capacity of the flow. This leads to the development of a deep hole (scour hole) around the bridge element, which in turn, changes the flow pattern causing a reduction in shear stress by the flow thus reducing its sediment transport capacity. The temporal variation of scour and the maximum depth of scour at bridge elements therefore mainly depend on the characteristics of flow, pier and river-bed material. The formation of the horseshoe vortex and the associated

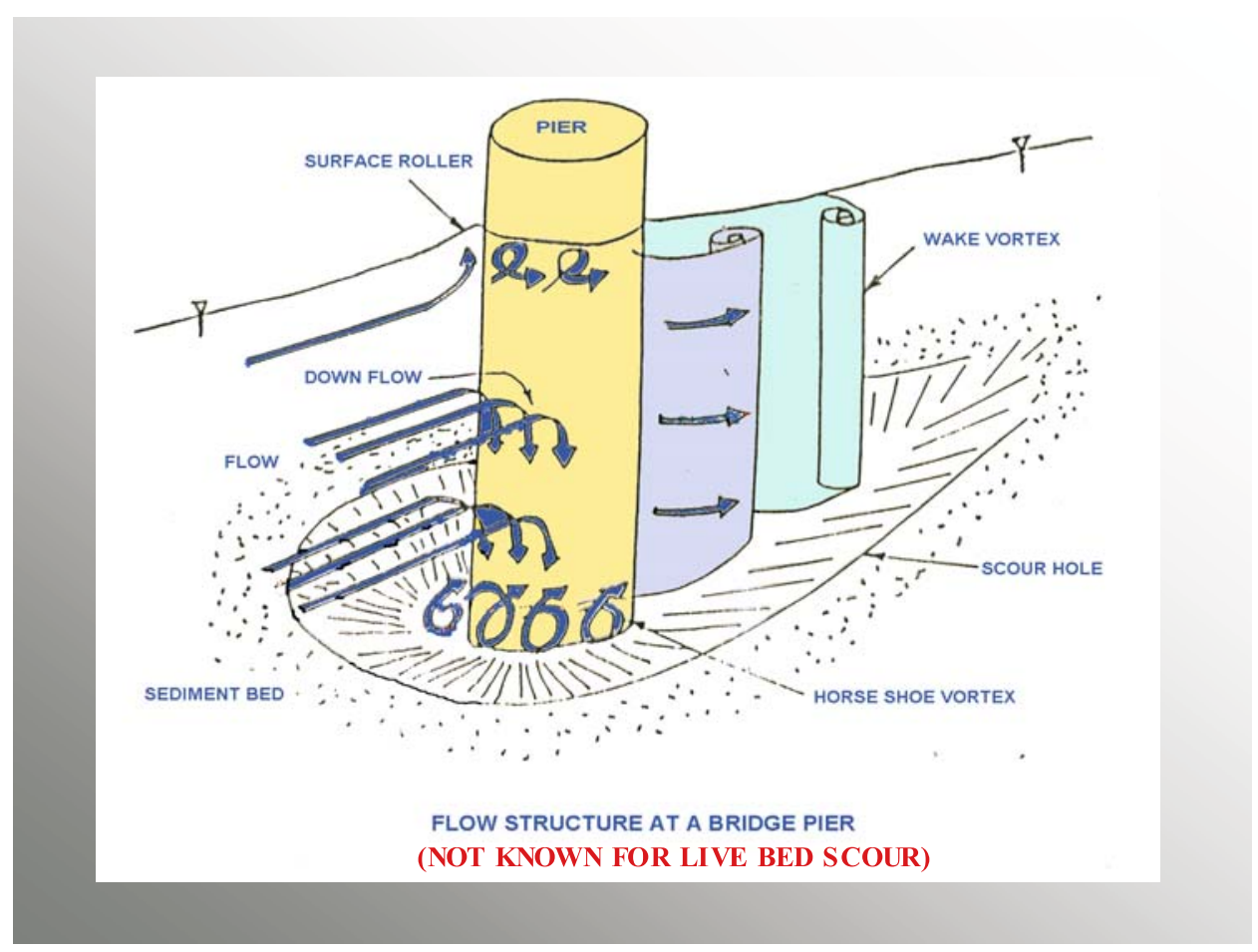

Figure 1. Flow pattern around bridge piers. 
downflow cause scour at different elements of a bridge such as pier, abutment and spur dike. The mechanism of scour around bridge piers has been studied by Kothyari et al (1992a \& b) whereas studies on the mechanism of scour around abutments and spur dikes are available in Kothyari \& Ranga Raju (2001). Vittal et al (1994) and Kumar et al (1999) investigated the effectiveness of several appurtenances for reduction of scour around bridge piers.

\section{Indian practice on estimation of design scour depth}

What is commonly known as Lacey's method of estimating regime depth of flow in loose bed alluvial rivers was developed by Lacey (1929) and Inglis (1944) mainly based on observations made in canals in India and Pakistan. This method is commonly used in India for estimation of scour depth also around bridge piers placed in alluvial rivers, and is recommended for design by the Indian Road Congress and Indian Railways. Recently, questions have been raised about its application to rivers in clayey or gravelly strata. The present paper is devoted to a detailed discussion and comments on Lacey-Inglis method and its limitations.

\subsection{Lacey-Inglis method}

During the early 20th century Lacey analysed data from stable irrigation channels flowing through loose sandy material in the Indo-Gangetic plain. These channels used to carry relatively less bed load since in the upstream reach of the channel a sediment excluder or ejector was provided. The analysis of field data gave the following two relations for depth (or hydraulic radius) $D_{L}$ and perimeter (or width) $P$ of the channel:

$$
\begin{aligned}
D_{L Q} & =0.47(Q / f)^{\frac{1}{3}}, \\
P & =4.75 \sqrt{Q} .
\end{aligned}
$$

Here $D_{L Q}$ is the normal scour depth in m below the design flood level, $Q$ the design flood discharge in $\mathrm{m}^{3} / \mathrm{s}$ and $f$ the Lacey's silt factor related to the median size of bed material $d$ by the equation:

$$
f=1 \cdot 76 \sqrt{d}
$$

$d$ being in mm. Inglis (1944) collected data from 17 bridges on alluvial rivers in India and found that maximum scour depth below the highest flood level (HFL), $D_{s e}$, when expressed in terms of computed depth of flow in the river $D_{L Q}$ using (1) gave

$$
D_{s e}=K D_{L Q}
$$

where $K$ varied from 1.76 to 2.59 with a mean value of 2.09 . Hence, according to Inglis

$$
D_{s e}=2 \cdot 0 D_{L Q} \text {. }
$$

According to the Indian Road Congress (IRC 1998 \& 2000) for natural channels flowing in alluvium the mean depth of scour below flood level can be calculated using the Lacey's formula

$$
D_{L q}=1 \cdot 34\left(q^{2} / f\right)^{1 / 3}
$$

wherein $D_{L q}$ is the mean scour depth (m) below design flood level, $q$ the design flood discharge intensity in $\mathrm{m}^{3} / \mathrm{s} / \mathrm{m}$ allowing for concentration of flow. 
Initially Lacey's equations (1) and (2) were meant for constant discharge flowing through channels in loose non-cohesive material having the bed material size in the range 0.13 to $0.43 \mathrm{~mm}$. Later, an analysis of data from some rivers in India flowing through Indo-Gangetic plain, it was stated that these equations also apply to meandering rivers at the bankful stage. The bankful discharge was defined by Inglis (1947) as 2/3 to 3/4 of the flood discharge, and it was basically the maximum discharge that the main river channel (excluding flood plain) carried. The bankful discharge has a return period of about 1.6 to 2 years. In the context of bridge scour, the designer applies these equations for a flood discharge of 50 to 100 year return period which is much greater than the bankful discharge.

\subsection{Comments on Lacey's method}

There is some reservation about the general applicability of Lacey's equations to stable channels and rivers flowing through sandy material. According to Garde \& Ranga Raju (2000) divergence from Lacey's equations has been observed by Inglis in India, Lane in USA, Blench in Canada, Leopold and Maddock in the case of rivers in USA and in Egypt. Two probable reasons attributed for this divergence are effects of lithology and sediment load carried by stream or channel. Data collected by Leopold \& Maddock (1953) as well as others indicate that flow depth is proportional to $Q^{0 \cdot 40}$. Since computed depth using Lacey's equation is used in Lacey-Inglis method, some discrepancy is likely to occur.

The Lacey-Inglis method is meant for non-cohesive sandy material with mean sediment size of about $0.15 \mathrm{~mm}$ to $0.43 \mathrm{~mm}$. In this size range the geometric standard deviation of the bed material would vary between 1.4 and 1.8 . The method is not valid outside this range. In the case of coarser material with larger standard deviation, as scour progresses, armouring occurs by selective removal of finer material from scour hole and hence smaller scour depth will occur. For very fine material, having cohesion, it is generally considered that there will be greater resistance to scour and hence reduced scour depth will result. However, recent studies (Ansari et al 2002) on scour in cohesive material revealed that depending upon antecedent soil moisture and drainage conditions prevailing in cohesive soils, the scour in them can be less, equal or even more than that in cohesionless material under similar flow and pier conditions. These effects are not considered in the Lacey-Inglis method.

As pointed out by Chitale $(1988,1993)$, the Lacey-Inglis method is valid for sandy rivers of meandering type, and should be used only in such cases. Further, it is known that in the case of rivers, scour at the bridge pier can be due to three reasons: (i) pier scour due to modification of the flow due to the presence of pier; (ii) scour due to contraction when channel width is reduced at the bridge site by road embankment and guide bunds; and (iii) scour due to nonuniform distribution of flow in the bridge waterway, which in turn is due to presence of bend, non-uniform cross section, and other obstructions. All these effects are inherent in scour depth calculated using the Lacey-Inglis method. Hence it is unreasonable to compare this scour depth with that calculated using the formulae based on laboratory studies where only the first category of scour is estimated. Further, the last two effects being particularly sitespecific, larger variations in scour depth are likely to occur which cannot be related to $Q$ and $f$ alone.

\section{Scour depth variation during the passage of floods}

The recent advances in research related to bridge pier scour give more emphasis on computation of temporal variation of scour depth for determining the design scour depth (Kothyari 


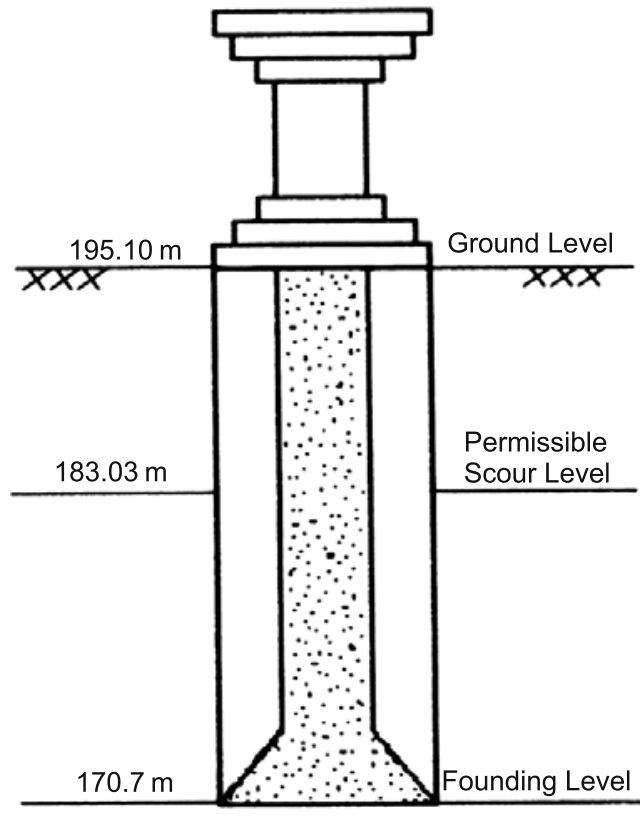

Figure 2. Details of pier and footing of bridge on Ganga at Garhmukteshwar.

et al $1992 a \& b$, Oliveto \& Hager, 2002, Mia \& Nago, 2003). The main logic behind such a philosophy is that for a given discharge in the river, the time required to develop equilibrium scour depth is very large (more than 3 to 4 days). Since the design flood flows do not last this long, they are not able to scour up to their maximum potential.

A detailed comparison of Lacey's scour depth with field observations from several countries is available in Garde \& Kothyari (1998) and Kothyari (2003). In order to further compare Lacey's estimate of scour depth with actual observations, the data on scour observations made at a railway bridge on river Ganga at Garhmukteshwar in Uttar Pradesh have been used here. The scour depth at several piers of the bridge was measured by lowering the lead weights into the river-bed around the piers.

These observations have been made by a person in charge of railway bridge at Garhmukteshwar between July 09, 1996 and September 21, 1996. The geometry of the piers of the bridge at Garhmukteshwar is shown in figure 2. The river-bed material therefore consists of fine sand; a silt factor equal to 1.0 is used (Ranga Raju et al 1997 and 1999). The observations by railways included concurrent measurements of discharge and scour depth. The temporal variation of river discharges, observed scour depth and scour depth estimated by Lacey's method [(1) and (5)] is presented in figures 3(a) and 3(b) respectively.

Figure 3(b) shows that observed values of scour depth only changed from about $10 \mathrm{~m}$ in the beginning of the flood to about $13 \mathrm{~m}$ during the passage of the flood peaks which occurred between the $40^{\text {th }}$ and $50^{\text {th }}$ day of the observation. Also, the increase in scour depth from a value of about $11 \mathrm{~m}$ to $13 \mathrm{~m}$ took place during the first ten days of the rise of river flows and beyond that period the observed scour depth remained almost constant despite the fact that the discharge was nearly doubled during the corresponding passage of the peak flood. The cause of such small increase in scour depth is presumally because during the passage of peak flows the rate of change of flow values was very large and the scour depth could not increase at this rate. 


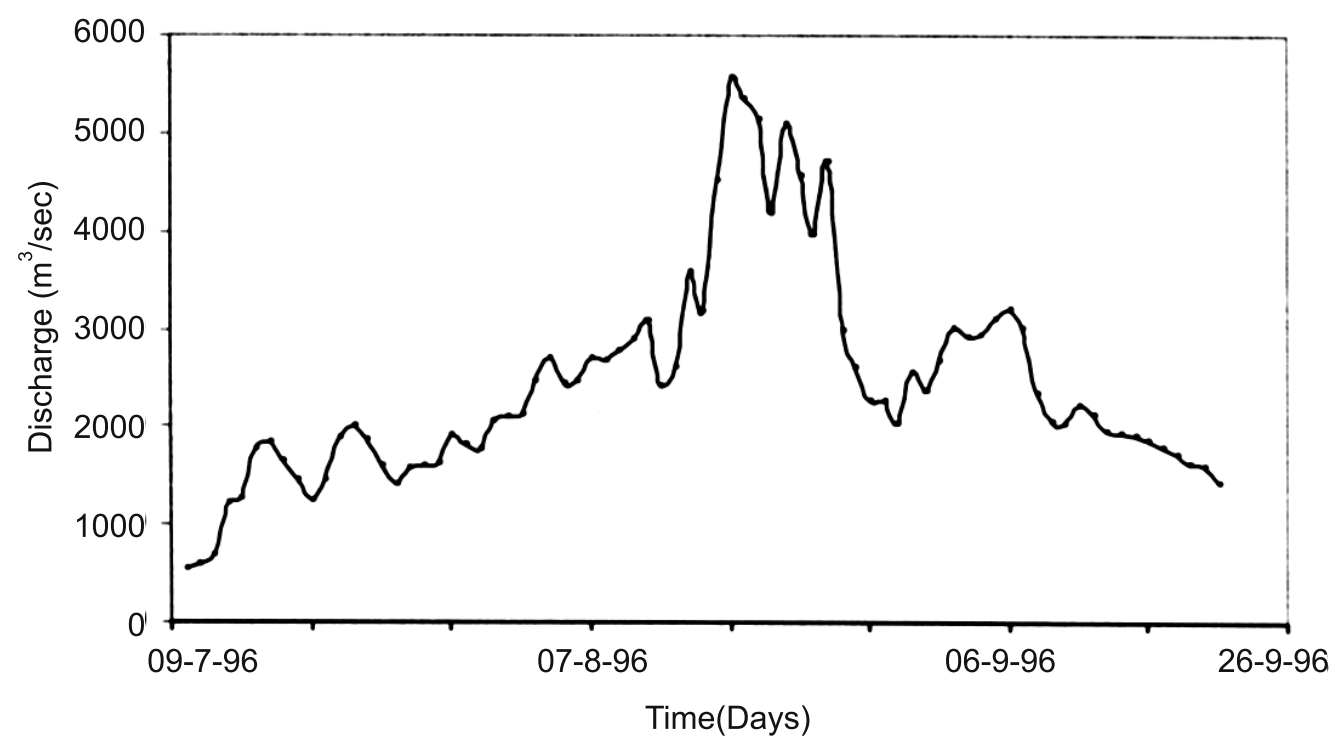

Figure 3a. Temporal variation of discharge of river Ganga at Garhmukteshwar (between July 9, 1996 and September 21, 1996).

The scour depth is reported to reduce during recession of the flood (i.e. beyond the observational period of 50 days). This is on expected lines as considerable deposition of the suspended sediment occurs during recession.

A comparison between corresponding values of observed scour depth and scour depth estimated by Lacey's method (figure 3(b)) reveals that Lacey's method underestimates the

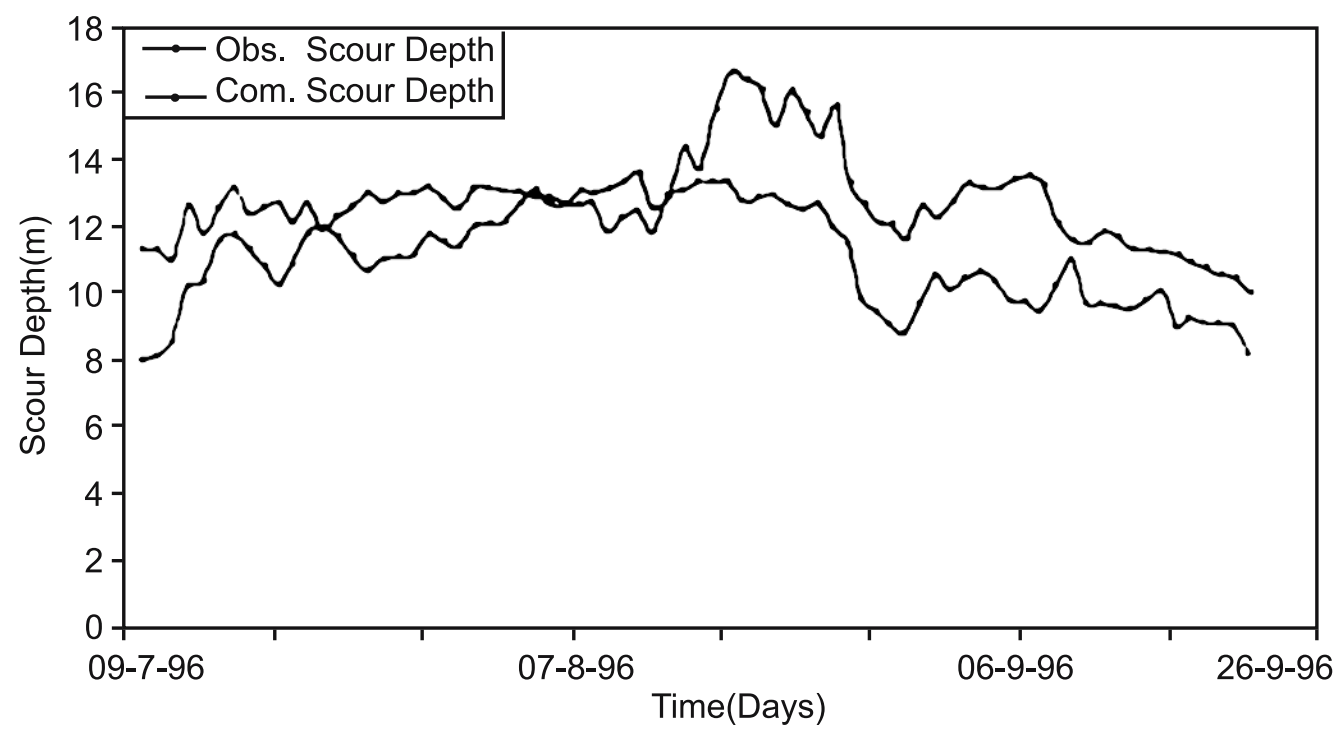

Figure 3b. Temporal variation of observed and computed values of maximum scour depth at piers of railway bridge on river Ganga at Garhmukteshwar (between July 9, 1996 and September 21, 1996). 

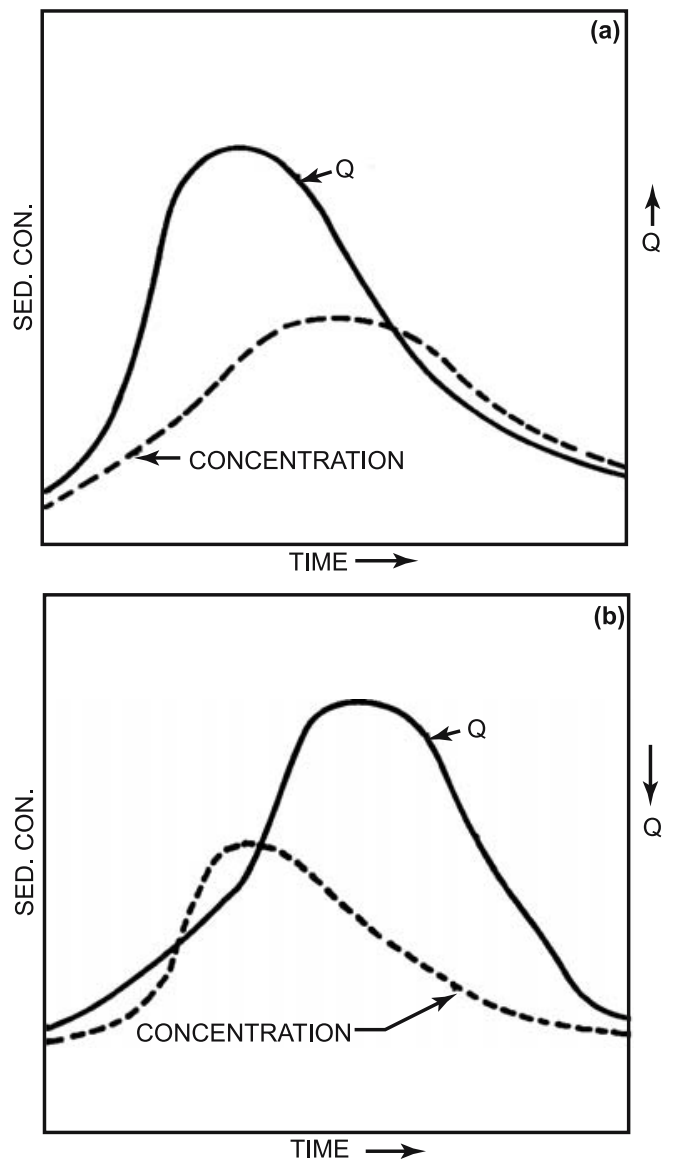

Figure 4. Scour and accretion during flood flows.

scour depth in the rising part of the hydrograph while the Lacey's estimate of scour is higher during passage of the peak flows and the recession part of the hydrograph.

Another effect during passage of floods also needs mention. It is known that in some streams there is general lowering of the river-bed during passage of flood; in many other streams, data indicate that the general bed of the river rose during the flood. These changes are usually rapid. Experience on such rivers indicates that changes in bed level during passage of flood are linked with changes in total sediment concentration during the flood. In fact, such a behaviour of the river can be related to a relative lag between the peak of flood hydrograph and the peak of sediment concentration hydrograph. The two cases are illustrated in figure 4 . In case (a), the flood peak occurs first followed by the sediment concentration peak. As the sediment concentration carried during the rising limb is relatively less, the river-bed is scoured during the rising limb of flood hydrograph, while the bed tends to aggrade during the falling limb because during the falling limb it is carrying relatively more sediment load. In case (b), the peak of sediment concentration occurs first followed by the peak of flood hydrograph. In this case, the stream carries relatively more sediment load during rising limb and relatively less during the falling limb. Hence, bed would aggrade during rising limb of hydrograph and degrade during falling limb. Such changes occur where flash floods occur; their occurrence would be less important on large rivers where floods occur and recede slowly. Without adequate data 
on river-bed elevations and water surface during floods, one would not know the extent of this effect. However, it needs to be emphasized that this effect is not explicitly considered in the Lacey-Inglis estimation.

The other investigations on scour reviewed by Kothyari (2003) indicate that scour at bridge piers is strongly affected by diameter or width of bridge pier, shape of nose, and orientation of flow with respect to pier axis. Scour depth can change from 30 to $50 \%$ or more in such situations. This would mean $K$ value in $D_{s e}=K D_{L Q}$ should depend on these parameters. This is again not considered in Lacey's method.

One may refer to scour depth equation proposed by Kothyari et al (1992b) for channels transporting sediment. The equilibrium scour below normal bed level $d_{s e}$ is given by

$$
d_{s e} / d=0 \cdot 88(b / d)^{0 \cdot 67}(D / d)^{0 \cdot 40} \alpha^{-0 \cdot 30} .
$$

In (7) $b$ is the pier diameter, $D$ the flow depth and $\alpha$ the opening ratio which equals $(B-b) / B$, where $B$ is centre-to-centre spacing between the piers. Equation (7) can also be written as:

$$
d_{s e} / D=0.88(b / d)^{0 \cdot 67}(D / d)^{-0 \cdot 60} \alpha^{-0 \cdot 30} .
$$

As already mentioned, $D_{s e}$ represents the scour depth below the HFL therefore, $D_{s e}=d_{s e}+D$. For simplification let the two exponents 0.67 and -0.60 of (8) be taken as 0.67 and -0.67 respectively. Now adding unity to both sides of (8) we obtain:

$$
\left[1+\left(d_{s e} / D\right)\right]=0 \cdot 88(b / D)^{0 \cdot 67} \alpha^{-0 \cdot 30}+1 \cdot 0 .
$$

Thus one can write:

$$
D_{s e} / D=0 \cdot 88(b / D)^{0 \cdot 67} \alpha^{-0 \cdot 30}+1 \cdot 0 .
$$

This indicates that at a relative scour depth below HFL, $D_{s e} / D$ is strongly dependent on the ratio (pier width/flow depth) and the opening ratio $\alpha$. In the field $\alpha$ is close to unity and hence its effect on $D_{s e} / D$ is likely to be small, but the effect of $b / D$ on scour which is significant is not reflected in constant $K$ value in the Lacey-Inglis method.

Equation (8) also indicates that $d_{s e}$ is proportional to $d^{-0 \cdot 07}$; hence, scour depth decreases with increase in sediment size. However, the effect is very small. This is true only when the sediment is nearly uniform i.e. $\sigma_{g}$, the geometric standard deviation is only slightly greater than unity. According to Garde (1972) and Kothyari (1995) the geometric standard deviation $\sigma_{g}$ is related to the median sediment size $d$ as:

$$
\sigma_{g}=1 \cdot 4 d^{0 \cdot 34}
$$

Here $d$ is in mm. As $\sigma_{g}$ increases some of the coarser non-moving sediment particles accumulate in the scour hole and tend to form an armour coat. As a result, the maximum scour depth in non-uniform sediments is much less than that in uniform sediments. This effect is also not considered in the Lacey-Inglis method. This particularly happens in gravel-bed rivers. In which Lacey's equations (1) and (2) are not valid. Further, the river-bed material being coarse and non-uniform, as the flood discharge reduces, paving is formed on the bed below which lies the parent non-uniform material. This phenomenon presents a situation of scour in layered materials. For these reasons the Lacey-Inglis method should not be used in gravel-bed rivers. 


\section{Codal provisions}

As regards scour estimation around bridge piers, two codal provisions are available in India, both of which depend on the Lacey-Inglis method with slight variation. The Indian Railway Standards (1985), IRC: 5 (1998) and IRC: 78 (2000) stipulate that in channels with alluvial beds where the width of effective linear waterway provided is not less than Lacey's width (equation (2)), Lacey's depth be calculated using (1). In case where, due to constriction of waterway, the width is less than Lacey's width, or where it is narrow and deep as in the case of incised rivers, Lacey's depth be calculated using the equation:

$$
D_{L q}=1 \cdot 34\left(q^{2} / f\right)^{1 / 3}
$$

Equation (11) is obtained by combining (11) and (2). In using (11) for computing $D_{L q}$, one must compute $q$ from $Q$ divided by effective linear waterway.

The Indian Road Congress Standard Specifications and the Code of Practice for Road Bridges IRC: 78 (2000) and IRC: 5 (1998) recommend use of (11) for computing $D_{L q}$ and then $D_{s e}=2 D_{L q}$. Further, both codal provisions give guidelines for estimating Lacey's silt factor $f$. The IRC codes recommend that the design discharge be increased from $10 \%$ to $30 \%$ (depending upon catchment area) for computation of design scour.

As indicated by Chitale (1988), the Lacey-Inglis method being empirical in nature, it is essential that it is used as recommended by Inglis; i.e. computing $D_{L Q}$ from (1) and then finding $D_{s e}$. Chitale (1988) showed that for data of Inglis for 17 bridges, if $D_{L q}$ is computed and then compared with the observed $D_{\text {se }}$, the magnitude of $K$ varies from 1.23 to 8.39 with a mean of $3 \cdot 78$. Hence, it would be wrong to take $K=2 \cdot 0$, when $D_{L q}$ is used as stipulated by IRC codal provision.

The railway bridge on river Ganga at Garhmukteshwar built in 1900 is still in operation. Design discharge for the bridge is not known (Sharma \& Asthana 1976). However, a flood of $12,748 \mathrm{~m}^{3} / \mathrm{s}$ passed safely through the bridge in 1924 (Sharma \& Asthana 1976). This flood magnitude is the highest over a period of 103 years and the same corresponded to a high flood level HFL of 200.25 m (Ranga Raju et al 1997). A waterway (span length) of $704.0 \mathrm{~m}$ is provided for the bridge. The value of $q$ for the condition of highest flood is $18.1 \mathrm{~m}^{3} / \mathrm{s} / \mathrm{m}$ (without further increase in the design flood magnitude as per the provisions of IRC). Taking $f=1.0$ (Ranga Raju et al $1997 \& 1999$ ) the value of $D_{L q}$ in (11) is $9.24 \mathrm{~m}$. The scour depth below HFL as per IRC code is $18.48 \mathrm{~m}$ which would produce the maximum scour level of $[200 \cdot 25(\mathrm{HFL})-18 \cdot 48]=181.77 \mathrm{~m}$. The maximum permissible scour level adopted for design of the bridge was $183.03 \mathrm{~m}$ (figure 2). It may thus be noted that the bridge foundation did not encounter the kind of scour magnitude during its life of 103 years so far, which is envisaged through IRC provisions. In this case thus the design scour depth as per IRC codes is probably much more safe.

It is also worthwhile to mention here that several other existing bridges over different rivers in the country are over a century old. The ones over Ganga at Sangam (Allahabad) and the old railway bridge on Yamuna at Delhi are a few examples. The foundation levels of these bridges were obviously not determined as per Indian Railway Standards (1985), IRC:78 and IRC:5 since these codes came into vogue much later. However, the fact remains that the foundation levels of the afore-mentioned and other bridges are at a level higher than required as per the provisions of codes of practice in India like IRC:78 and IRC:5. They have served their purpose efficiently for over a century even if they have encountered the design floods. It is also to be mentioned that the new bridges being built in the vicinity of these century-old existing 
bridges are being provided much lower foundation levels resulting in increased construction costs.

In the light of the above, it is imperative to base the provisions of the codes being practised in India on scientific studies for scour around bridge piers and abutments. It is necessary to find the range of bed material size where Lacey's equation is applicable apart from the fact that Lacey's equation does not cover other parameters except discharge and size of bed material.

A comparison of estimates of scour depth obtained through various relationships with field observations from several countries revealed (Garde \& Kothyari, 1998 \& Kothyari 2003) the estimates of scour depth following Lacey's method to be less accurate than the methods of Kothyari-Garde-Ranga Raju (Kothyari et al 1992a, b) and Melville-Sutherland (Melville \& Sutherland 1988).

It is therefore clear that there is a strong need for reviewing the codal provisions for estimation of scour being followed in India to make more rational recommendations for design against scour based on scientific investigations.

\section{Conclusions}

It can be seen that the Lacey-Inglis method is basically empirical and essentially gives total scour below HFL in the case of meandering rivers in flood plain in sandy material. It is based on data from only seventeen bridges - a relatively small number. The Lacey-Inglis method is meant for non-cohesive sandy material with mean sediment size of about $0.15 \mathrm{~mm}$ to $0.43 \mathrm{~mm}$ and having the geometric standard deviation of the bed material about 1.4 to 1.8 . However, the method is commonly used in design of railway and road bridges in India. When compared with other methods in the light of principles of river hydraulics, the limitations of Lacey-Inglis method become apparent.

\section{Notations}

$b \quad$ pier diameter

$B \quad$ centre-to-centre spacing between piers

$d \quad$ median size of bed material

$d_{s e} \quad$ equilibrium scour depth below river-bed level

$D \quad$ flow depth

$D_{L q} \quad$ mean scour depth below high flood level

$D_{L Q} \quad$ normal scour depth below high flood level

$D_{s e}$ maximum scour depth below high flood level

$f \quad$ Lacey's silt factor

$K \quad$ constant

$P \quad$ perimeter of the channel

$q \quad$ design flood discharge intensity

$Q \quad$ design flood discharge

$\alpha \quad$ opening ratio

$\sigma_{g} \quad$ geometric standard deviation.

\section{References}

Ansari S A, Kothyari U C, Ranga Raju K G 2002 Influence of cohesion on scour around bridge piers. J. Hydraul. Res. 40: 717-729 
Chitale S V 1988 Estimation of scour at bridge piers. J. Irrigation and Power (CBIP) 45:

Chitale S V 1993 Indian practice of scour estimation-limitations. J. Irrigation and Power 50:

Garde R J 1972 Bed material characteristics of alluvial streams. J. Sediment. Geol. 7:

Garde R J, Ranga Raju K G 2000 Mechanics of sediment transportation and alluvial stream problems. (New Delhi: New Age)

Garde R J, Kothyari U C 1998 Scour around bridge piers. J. Ind. Nat. Acad. New Delhi, 64: 569-580

Gupta R K 2003 Case studies of bridges on alluvial clayey and boulder streams with regard to pier scour. Nat. Workshop on bridge scour, river training and protection works, New Delhi

Huber F 1991 Update: bridge scour, civil engineering, New York: ASCE

Indian Railway Standards, IRS 1985 Code of practice for the design of sub-structures and foundations of bridges

Inglis C C 1944 Maximum depth of scour at heads of guide banks, groyens, pier noses and downstream of bridges, Annual Report (Technical), CWPRS, Pune

Inglis C C 1947 Meanders and their bearings on river training. Proc. ICE, London, Maritime Paper No. 7

IRC 1998 Standard specifications and code of practice for road bridges, section 1, IRC: 5-1998

IRC 2000 Standard specifications and code of practice for road bridges. section-VII, IRC: 78-2000

Kothyari U C 1995 Frequency distribution of river-bed materials. J. Sedimentology 42: 283-291

Kothyari U C 2003 Bridge pier scour in gravel - cobble and cohesive bed rivers, Report submitted to the IRC - sub-committee to review the aspects of scour around bridge foundations

Kothyari U C, Ranga Raju K G 2001 Scour around spur dikes and bridge abutments. J. Hydraul. Res. 39: $367-374$

Kothyari U C, Garde R J, Ranga Raju K G 1992a Temporal variation of scour around circular bridge piers. J. Hydraul. Eng. 118: 1091-1106

Kothyari U C, Garde R J, Ranga Raju K G 1992b Live-bed scour around cylindrical bridge piers. J. Hydraul. Res. 30: 701-715

Kumar V, Vittal N, Ranga Raju K G 1999 Reduction of scour around bridge piers using slots and collars. J. Hydraul. Eng. 126:

Lacey G 1929 Stable channels in alluviums. J. Institution of Engineers, Paper No. 4736, 229:

Leopold L B, Maddock T 1953 The hydraulaic geometry of stream channels and some physiographic implications. USGS Professional Paper 252

Melville B W, Sutherland A J 1988 Design methods for local scour at bridge piers. J. Hydraul. Eng. 114:

Mia MF, Nago H 2003 Design method of time-dependent local scour at circular bridge pier. J. Hydraul. Eng. 129: 420-427

Oliveto G, Hager W H 2002 Temporal variation of clear-water pier and abutment scour. J. Hydraul. Eng. 128: 811-820

Ranga Raju K G, Mittal M K, Kothyari U C 1997 Protection of left bank of the river Ganga near Garhmukteshwar railway bridge. Dept. of Civil Engg. IIT Roorkee, June

Ranga Raju K G, Mittal M K, Kothyari U C 1999 Measures for control of erosion of left bank of the river Ganga near Garhmukteshwar railway bridge. Dept. of Civil Engg. IIT Roorkee, March

Sharma H D, Asthana B N 1976 A study of waterway for bridges and barrages. J. Irrigation and Power, CBIP 331-344

Vittal N, Kothyari U C, Haghighat M 1994 Clear water scour around bridge-pier group. J. Hydraul. Eng. 120: 1309-1318 